\title{
P-0376 - Postprandial control of glycemia in patients with type 1 diabetes treated with insulin pumps during hospitalization
}

\author{
J. Krzymien ${ }^{1}$, P. Ladyzynski², P. Foltynski², M. Rachuta ${ }^{1}$ \\ 1 Medical University of Warsaw, Department of Diabetology and Internal Medicine, Warsaw, Poland. \\ 2 Nalecz Institute of Biocybernetics and Biomedical Engineering, Polish Academy of Sciences, Warsaw, Poland.
}

\begin{abstract}
Aim
The aim of this study was to compare the efficacy and safety of simple and dual-wave boluses calculated by a physician with or without an assistance of the voice-driven bolus calculator applied in patients with type 1 diabetes treated with pumps during hospitalization.
\end{abstract}

\section{Background}

Many patients treated with continuous subcutaneous insulin infusions do not achieve adequate glycemic control. Particular difficulties occur during hospitalization due to changes in calorie composition and seasons of meals. Clear guidelines have not been yet developed for establishing the dose and duration of insulin bolus, to prevent the increase of the plasma glucose concentration after eating mixed meals. Bolus calculation is based on carbohydrate content of a meal. In case of dual wave boluses the protein and fat content is also taken into account.

\section{Method}

The study was performed on 30 patients with type 1 diabetes treated with insulin pumps randomly assigned to one of two study groups. In the first group (age: $23.5 \pm 3.8$ years, HbA1c: $8.6 \pm 1.8 \%$ ) the type of bolus and the insulin dose were decided by the physician based on the content of meals calculated by a dietician. In the second group (age: $23.7 \pm 5.4$ years, HbA1c: $8.5 \pm 1.3 \%$ ) the physician was assisted by the VoiceDiab system, which calculates insulin doses based on the verbal description of meals. The boluses suggested by the system were approved or modified by the physician. Each study participant was monitored with the continuous glucose monitoring system.

The following parameters were monitored in each study group: the number of simple and dual-wave boluses before the main meals, the mean plasma glucose concentration, the percentage of time when plasma glucose concentration (PGC) was higher than $70 \mathrm{mg} / \mathrm{dl}$ and lower than $180 \mathrm{mg} / \mathrm{dl}$, the maximum increase of PGC after the main meals, the number and duration of hypoglycemia episodes (glucose concentration equal or lower than $70 \mathrm{mg} / \mathrm{dl}$ ).
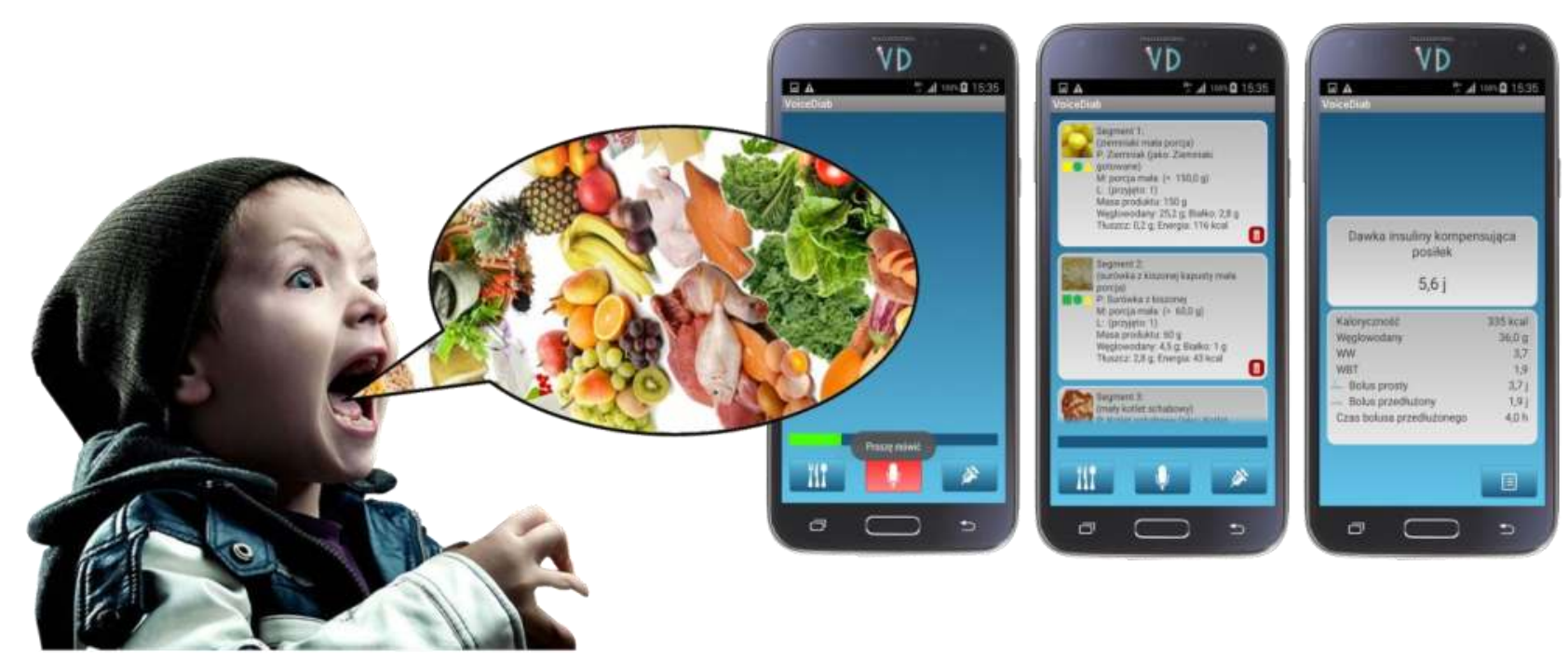

\section{Results}

In the first group $75 \%$ of all boluses were simple and in the second group this percentage was significantly lower and equal to $52 \%$. The average plasma glucose concentration and the percentage of time with PGC between $70 \mathrm{mg} / \mathrm{dl}$ and $180 \mathrm{mg} / \mathrm{dl}$ were similar in both groups $(131 \pm 15 \mathrm{mg} / \mathrm{dl}$ vs. $135 \pm 16 \mathrm{mg} / \mathrm{dl}, \mathrm{p}=0.42$ and $76 \pm 7 \%$ vs. $75 \pm 7 \%$, $\mathrm{p}=0.79$, respectively). The maximum increase of PGC after breakfast was equal to $77 \pm 25 \mathrm{mg} / \mathrm{dl}$ vs. $85 \pm 33 \mathrm{mg} / \mathrm{dl} \quad(\mathrm{p}=0.37)$, after lunch: $67 \pm 30 \mathrm{mg} / \mathrm{dl}$ vs. $72 \pm 30 \mathrm{mg} / \mathrm{dl}(\mathrm{p}=0.55)$ and after dinner: $71 \pm 24 \mathrm{mg} / \mathrm{dl}$ vs. $77 \pm 17 \mathrm{mg} / \mathrm{dl}(\mathrm{p}=0.11)$, in the first and the second study group, respectively. In the first group the hypoglycemia episodes were noted $2.1 \pm 0.8$ times per day whereas in the second group $2.0 \pm 1.3$ per day $(\mathrm{p}=0.77)$. The daily duration of hypoglycemic episodes was equal to $120 \pm 70 \mathrm{~min}$ in the first group and $95 \pm 74 \mathrm{~min}$ in the second group $(\mathrm{p}=0.35)$.

Carbohydrate exchanges (CE) and calorie meal's content counting by dietician and system.

\begin{tabular}{|l|c|c|c|c|c|} 
Meal & N & \multicolumn{2}{|c|}{$\begin{array}{c}\text { Carbohydrate } \\
\text { exchanges }\end{array}$} & \multicolumn{2}{c|}{$\begin{array}{c}\text { Calorie meal } \\
\text { contents }\end{array}$} \\
\cline { 3 - 6 } & & $\begin{array}{c}\text { Dietician } \\
\text { CE } \pm \text { SD }\end{array}$ & $\begin{array}{c}\text { System } \\
\text { CE } \pm \text { SD }\end{array}$ & $\begin{array}{c}\text { Dietician } \\
\text { Kcal } \pm \text { SD }\end{array}$ & $\begin{array}{c}\text { System } \\
\text { Kcal } \pm \text { SD }\end{array}$ \\
\hline Breakfast & 110 & $3.8 \pm 0.9$ & $4.1 \pm 0.9$ & $388 \pm 85$ & $381 \pm 85$ \\
\hline I snack & 81 & $1.1 \pm 0.4$ & $1.1 \pm 0.5$ & $92 \pm 36$ & $90 \pm 28$ \\
\hline Lunch & 130 & $5.5 \pm 1.0$ & $5.5 \pm 1.0$ & $503 \pm 21$ & $451 \pm 97$ \\
\hline II snack & 100 & $1.2 \pm 0.4$ & $1.4 \pm 0.4$ & $58 \pm 31$ & $58 \pm 28$ \\
\hline Supper & 114 & $3.9 \pm 0.9$ & $4.2 \pm 0.9$ & $410 \pm 86$ & $397 \pm 93$
\end{tabular}

\section{Discussion}

We noted that glycemic control in both study groups was similar in respect to the mean plasma glucose concentration and the maximum increase of PGC. Attempts to optimize postprandial PGC resulted in frequent and long-lasting hypoglycemic episodes.

The physician was using dual-wave insulin boluses more frequently when she / he was supported by the VoiceDiab system and in this case we observed a tendency towards shorter duration of hypoglycemic episodes.

Operation of the VoiceDiab system. 